\title{
Implementation of Performance Measurement Systems at PT. Pos Indonesian
}

\author{
Helly Siti Halimah ${ }^{1,2^{*}}$, Hamka ${ }^{1,2^{*}}$, Mohamad Jupri ${ }^{12^{*}}$, Ruly Budiono ${ }^{1}$, Abdul Malek A Tambi ${ }^{3}$ \\ ${ }^{\text {I}}$ Akademi Keuangan \& Bisnis Indonesia Internasional (AKBII), Bandung, Indonesia \\ ${ }^{2}$ Post Graduate at Faculty of Economics and Management Science, Universiti Sultan Zainal Abidin, Terengganu, Malaysia, \\ ${ }^{3}$ Faculty of Economic and Management Science, Universiti Sultan Zainal Abidin, Terengganu, Malaysia.
}

*Corresponding authore-mail address: hellyunisza@gmail.com,djufriliga@gmail.com,hamka1509@gmail.com

\begin{abstract}
This paper aims to carry out performance measurement at PT. Pos Indonesia, which consists of measurements of financial and non-financial performance. The preparation of this paper uses the study method of various literature from various international article sources. Public sector organizations or institutions in implementing their financial and non-financial performance measurements use a variety of steps. Therefore, the managers of PT. Pos Indonesia must adjust the appropriate performance measurement system, such as what will be used by PT. Pos Indonesia, according to the conditions of each PT. Pos Indonesian.
\end{abstract}

Keywords: financial measurement, financial performance, non-financial performance, PT. Pos Indonesian.

\section{Introduction}

Pos Indonesia is an Indonesian State-Owned Enterprise/Badan Usaha Milik Negara (BUMN) engaged in postal services. At present, the Pos Indonesia business entity form is a Limited Liability Company (Perseroan Terbatas) and is often referred to as PT. Pos Indonesian. This form of business of Pos Indonesia is based on Government Regulation of the Republic of Indonesia Number 5 of 1995 (Peraturan Pemerintah Republik Indonesia Nomor 5 Tahun 1995). The Government Regulation contains the transfer of the initial form of Pos Indonesia in the form of a Public Company/Perusahaan Umum (Perum) to a state-owned company. Established in 1746, Pos Indonesia shares are wholly owned by the Government of Indonesia. Currently, Pos Indonesia does not only provide postal and courier services but also financial, retail and property services, which are supported by a network of points of more than 4,000 post offices and 28,000 post agents spread throughout Indonesia.

PT. Pos Indonesia is an organization under the auspices of the government. The role of PT. Pos Indonesia in Indonesia is very important for the community because, with a large number of government institutions in Indonesia, these institutions are expected to be able to prioritize community satisfaction as well as several matters relating to their accountability to be more transparent.

To realize the goals of PT. Pos Indonesia in serving the community fully, PT. Pos Indonesia needs a budget that matches the needs of the organization in serving the community. The budget is given to PT. Pos Indonesia is not necessarily used alone but must also be analyzed in order to measure the success of the performance of PT. Pos Indonesia. Performance measurement at PT. Pos Indonesia used to assess the 
accountability of PT. Pos Indonesia (public sector organization) is in producing services to the community better.

\section{Theoritical Review}

According to Schmidt \& Günther (2016), the performance measurement system in public sector organizations was a series of systems that have the aim to help public management make strategic decisions through financial information and non-financial information. Performance measurement systems in public sector organizations can be a means of controlling these organizations because they set a reward and punishment system.

The basis for performance measurement in public sector organizations is as a form of accountability of the organization to the public and helps improve performance in government organizations and for the allocation of resources on target.

The objectives of the performance measurement system include

1) communication about better strategies,

2) balance measurement of financial and non-financial performance,

3) accommodate the understanding of the interests of management from top-level to bottom level management, and

4) based on an individual approach to achieving rational satisfaction and ability.

Information used to measure performance in public sector organizations is

1) financial information, which is carried out by measuring and analyzing actual performance variance with budgeted performance variance, and

2) non-financial information, which is carried out by increasing confidence in the quality of public sector performance by applying the Balanced Scorecard.

Measurement-based on the Balanced Scorecard involves several main aspects including financial, public satisfaction, internal process efficiency, and learning and growth (Iwona and Okouma, 2017).

Performance indicators are used to analyze whether the activities carried out by public sector organizations are running efficiently and effectively. To determine performance indicators, several things need to be considered including service costs, usage, quality and service standards, service coverage, and satisfaction (Greiling, 2005).

In the study of Sole \& Schiuma (2010), highlighting fundamental problems related to the implementation of performance measurement systems in public organizations. This research has a dual contribution. It analyzes the factors that influence the adoption and implementation of performance measures in public organizations. On the other hand, present the results of descriptive statistics of the survey highlighting the position of Italian institutions concerning the use of performance measures. Empirical investigations have been based on the definition of a framework identifying factors at the basis of the spread of performance measures. The proposed framework can be used for normative and descriptive purposes because it can encourage managers in public organizations to understand and hinder the effective implementation of the Performance Measurement System (PMS). Regarding empirical results, they provide interesting insights for assessing the use of performance measures in Italian public administration. At this stage of the study, only descriptive results have been presented. They point out that the use of measures in Italian public administration has not been widespread and in terms of their adoption and implementation there are also shortcomings.

In the study of Goh (2012), it showed that three important factors need to be considered in the effective implementation of performance measurement systems in the public sector. They are managerial wisdom, learning, and evaluative organizational culture and stakeholder involvement.

In Sarr's study (2015), it was said that to monitor public trust in health services in the Netherlands which was used as a performance indicator for health care for eight years, from 1997 to 2004 . The results of this study were fluctuations in health service trust that were relatively small and in a range of the same one. Public trust changes only slightly every year and these changes are difficult to interpret.

The results of Bracci and Maran's research (2011), it provided a structured picture of state-of-the-art performance measurement in the German public sector, taking all federal levels into account and offering 
ideas for improvement in performance measurement. The full potential of performance measurement can be augmented by transaction costs and opportunities for performance measurement and to the conditions under which performance measurement can support the learning process of the organization.

Hawke (2012) said that Australia's public sector performance management arrangements have been defined by strong external (political), structural and technical factors. This has been a very positive feature in achieving a stable and sophisticated system. This research shows that more emphasis on management, behavioral and cultural factors can continue to focus more on the benefits of improved techniques for further reform.

The research of Mimba et al. (2007), it argued that public sector organizations in developing countries will face an unbalanced position, namely the imbalance between demand and supply of performance information. More precisely, public sector reform - which was partly stimulated by the increased involvement of some stakeholders - led to an increase in demand for performance information but, due to low institutional capacity and high levels of corruption, this increase in demand was not always followed by an adequate supply of performance information.

The main concern in the study conducted by Astriani (2015), it was the local government in Indonesia how local governments should develop performance measurement indicators. This research has proposed one of the many ways to develop performance measurement indicators, only giving an outline as a general picture. A more detailed technical guideline or method is needed to complete the proposed steps of developing indicators, such as technical methods for gaining community involvement, ways to link performance to civil servant remuneration, and steps to lead a successful transition.

According to Käyhkö (2011), the government of New South Wales (NSW) applied a financial framework designed to encourage government service providers to be more efficient and effective. NSW Treasury uses Data Envelopment Analysis (DEA) to measure the efficiency of key government service providers, such as police, courts, and hospitals. The results show that the NSW police patrol (local police district) on average, reduced the use of inputs by 13.5 percent through better management, and 6 percent if patrols could be restructured to achieve optimal scale. The results also showed that differences in the operating environment, such as location and socioeconomic factors, were not significant in their effects on the efficiency of police patrols.

According to Markic (2014), the research conducted focuses on empirical evidence about the use and usefulness of performance measurement in the public sector. It starts with consideration of features from the public sector that make use of complex performance measures. Some of these responses increase efficiency, but others don't and fall into the 'game' category. Small, generally, existing assessments about performance measurement have led to improvements in services.

Arnaboldi \& Azzone (2010), they examined good practices in measuring the performance of systems implemented at universities in Italy for 11 years. This research highlights two important elements in the translation process: role controversy and the importance of the emergence of a diversity of actors approach, from a functional perspective, implementation is considered successful when all controversies have been resolved; The study instead found that the controversy represented an "important risk" for STDs. Important because they maintain interest and discussion in the network; and risks because they always challenge the possibility of achieving socio-technical compromise.

Ballantine et al. (1998) observed improved management in public health services in the United Kingdom and Sweden has driven changes in cost and performance measurement (PM). This finding shows the risk of some strategic priorities, perhaps supported by certain groups of stakeholders, becomes too dominant and thus upsets the balance between the various dimensions of performance. Therefore, the service perspective on PMS design can be a useful complement to focus on strategic objectives, because it challenges system designers to carry out a more in-depth analysis of operating conditions.

Lin and Lee (2011), in the research conducted, they showed that the different nature of the reciprocal relations between these three main stakeholders will influence the extent to which performance measurements in service-focused service organizations will be balanced and integrated.

According to Choong (2013) in his research, approach by reviewing and checking the Performance Measurement System (PMS) for measurement from 1990 (January) to 2012 (November). The results show that this review contributed to and updated the existing literature on PMS in three ways: 
identification of gaps in terms of practical use and academic research; Suggested solutions in the form of a conceptual framework for improving measurement and performance measurement using the correct PMS features.

Harrison et al. (2012) researched elementary and secondary schools in the state of Florida to observe how stakeholders respond to performance measurements. The results show that Florida changed the school grading system in 2002 and studied the extent to which private contributions to schools are responsive to the information contained in school grades. The results also show that school grades can have a large effect on the ability of schools to obtain private contributions.

Veledar et al. (2014) conducted research to identify some practical research and practitioners of fundamental issues that must be investigated to improve the understanding and practice of the design and implementation of PMSs in public organizations. This study reveals that an important challenge for the adoption and implementation of performance measurement systems in public sector organizations is to evaluate and manage intangible resource capabilities and assets.

Fahlevi (2015), in his research using a sample of administrative practitioners as a benchmarking to assess organizational performance. The results showed benchmarking knowledge and information is a fundamental resource development strategy.

Martin et al. (2014) measured the performance of public services through local networks using the Comprehensive Area Assessment (CAAS). CAAS encourages agencies to strive to achieve better working partnerships but does not provide efficiency on strong comparative data to enable managers' performance against other regions or identify good practices elsewhere. Policymakers hope citizens will use CAAS to hold conventions to be held accountable but the Media fails to appeal to the public interest.

Sandgren (2017) undertook the development of performance measurement (PM) in the Swedish university sector, which has been subject to increasing emphasis on management with goals since the early 1990s. The results show that although the goal-directed model cannot be completely rejected as the heuristic informs of recent changes in PM, the institutional-oriented perspective prescribes considerably enriching analysis by making it less static and more contextual information.

The research conducted by Rantanen et al. (2007), they identified specific problems faced by Finnish public sector organizations in designing and implementing performance measurement systems (PMS). The results show that the design and implementation of processes in Finnish public sector organizations are significantly different from the way they are manifested in the private industry. The four reasons underlying the problem in public sector organizations are as follows: there are many stakeholders with conflicting needs; final product and destination not explained; lack of property ownership and lack of management skills.

According to Zhonghua \& Ye (2012), their research explored inspiration in measuring the performance of the Chinese public sector, which is based on previous literature reviews including influential factors, methods, and indicators of evaluating public sector performance. The results of various foreign literature indicate that there are three evaluations of the performance of the Chinese public sector, including as follows. First, under the market economy, the Chinese public sector is demanded to be market-oriented, and manage it more autonomously. Second, the characteristics of the public sector itself determine that the goals and objectives of the assessment are multiple. Third, performance appraisal requires collaboration between human resource management departments and IT departments.

According to Ayoup et al. (2012), the results of the study stated that public sector organizations can use the Balanced Scorecard after modifying the initial concept of the balanced scorecard used for business organizations. The first such modification is, the mission of public organizations so that the main objective of public sector organizations is to provide services to the public effectively and efficiently. Second, modify the position between the financial perspective and the customer. Third, the customer perspective is changed to the customer and stakeholder perspective and fourth, the growth and learning perspective is replaced by the employee and organizational capacity perspective. 


\section{Conclussion}

Based on the discussion of performance measurement at PT. Pos Indonesia both from theory and the results of research conducted it can be concluded that the success of performance measurement at PT. Pos Indonesia in serving the community is not only measured from a financial perspective but can also be measured through a non-financial perspective, which is realized in the Balanced Scorecard. Besides, performance measurements at PT. Pos Indonesia can be used as an organizational control tool in the form of awards or sanctions given to the organization, performance measurement is expected to improve government performance to be better, and can be used as government decision making.

\section{References}

Arnaboldi, M. \& Azzone, G. (2010). Constructing Performance Measurement in the Public Sector. Critical Perspectives on Accounting, 21(4), 266-282.

Astriani, N. J. (2015). Local Government Performance Measurement: Developing Indicators Based on IWA 4: 2009. Public Organization Review, 15, 365-381.

Ayoup, H., Omar, N. Hj. \& Rahman, I. K. A. (2012). Implementation of Balanced Scorecard (BSc) in a Malaysian GLC: Perceptions of Middle Managers. Asia-Pacific Management Accounting Journal, 7(2), 99-126.

Ballantine, J., Brignall, S. \& Modell, S. (1998). Performance Measurement and Management in Public Health Services: A Comparison of U. K. and Swedish Practice. Management Accounting Research, 9(1), 71-94.

Bracci, E. \& Maran, L. (2011). Performance Measurement in the Public Sector: Some Theoretical and Practical Reflections. Working Papers 201121, University of Ferrara, Department of Economics.

Choong, K. (2013). Understanding the Features of Performance Measurement System: A Literature Review. Measuring Business Excellence, 17(4),102-121.

Fahlevi, H. (2015). The Application of Benchmarking in the Public Sector - Lessons from Germany. Jurnal Ilmiah Administrasi Publik, 1(1), 1-7.

Goh, S. C. (2012). Making Performance Measurement Systems More Effective in public Sector Organizations. Measuring Business Excellence, 16(1), 31-42.

Greiling, D. (2005). Performance Measurement in the Public Sector: The German Experience. International Journal of Productivity and Performance Management, 54(7), 551-567.

Harrison, J. A., Rouse, P. \& De Villiers, V. J. (2012). Accountability and Performance Measurement: A Stakeholder Perspective. JCC: The Business and Economics Research Journal, 5(2), 243-258.

Hawke, L. (2012). Australian Public Sector Performance Management: Success or Stagnation?. International Journal of Productivity and Performance Management, 61(3), 310-328.

Iwona, S. I. \& Okouma, O. G. V. (2017). Performance Management: How the Swedish Administration of Transportation for the Disabled Succeeded: A Case Study of Transportation Service for the Disabled, the Municipality of Gothenburg. Journal of Public Administration and Policy, 10(1), 141-175.

Käyhkö, E. (2011). Public Accountability to Citizens: From Performance Measures to Quality Thinking. Paper. Public Management Research Conference, in Syracuse, NY, May 2011, 1-31.

Lin, J. S. \& Lee, P. Y. (2011). Performance Management in Public Organizations: A Complexity Perspective. International Public Management Review, 12(2), 81-96.

Martin, S., Downe, J. \& Measurement, P. (2014). Public Value Management, Measurement and Reporting. Studies in Public and Non-Profit Governance, 3, Emerald Group Publishing Limited.

Markic, D. (2014). A Review on the Use of Performance Indicators in the Public Sector. TEM Journal, 3(1), 22-28.

Mimba, N. P. S. H., Jan van Helden, G. \& Tillema, S. (2007). Public Sector Performance Measurement in 
Developing Countries. Journal of Accounting \& Organizational Change, 3(3), 192-208.

Rantanen, H., Kulmala, H. I., Lönnqvist, A. \& Kujansivu, P. (2007). Performance Measurement Systems in the Finnish Public Sector. International Journal of Public Sector Management, 20(5), 415-433.

Sandgren, M. (2017). How Managers, Academics and Students Use Performance Information Under Conditions of Conflicting Institutional Logics and Ambiguity: A Case Study of a Swedish University. Master Thesis. Master of Science in Business Administration with specialization Accounting and Auditing, Spring 2017.

Schmidt, U. \& Günther, T. (2016). Public Sector Accounting Research in the Higher Education Sector: A Systematic Literature Review. Management Review Quarterly, 66(4), 235-265.

Sole, F. \& Schiuma, G. (2010). Using Performance Measures in Public Organisations: Challenges of Italian Public Administrations. Measuring Business Excellence, 14(3), 70-84.

Sarr, B. (2015). Assessing Public Sector Performance in Developing Countries: Four Essays on Public Financial Management and Public Service Delivery. Economics and Finance, Université d'Auvergne Clermont-Ferrand I, 1-176.

Veledar, B., Bašic, M. \& Kapic, J. (2014). Performance Measurement in Public Sector of Transition Countries. Business Systems Research, 5(2), 72-83.

Zhonghua, C. \& Ye, W. (2012). Research Frontiers in Public Sector Performance Measurement. Physics Procedia, 25, 793-799. 